\title{
A Comparative Description of Affixation Processes in English and Yoruba for ESL Pedagogy
}

\author{
Adebola Omolara Adebileje \\ Department of English, College of Humanities, Redeemer's University, KM 46, Lagos-Ibadan Express Way, \\ Redemption Camp, Mowe. Ogun State, Nigeria
}

\begin{abstract}
This study describes the affixation processes involved in English and Yoruba word formation systems with the aim of identifying areas of differences and similarities for pedagogic implications. All languages have their systems of arranging words (morphology) to form sentences which are ultimately used to express and communicate information. The study is premised on the contrastive analysis hypothesis which postulates that similarities between the two languages will cause no difficulties ('positive transfer'), but differences will, due to 'negative transfer' (or 'interference'). Analyses of English and Yoruba derivational and inflectional processes of affixation reveal that the English language offers itself to both prefixation and suffixation morphological processes but the Yoruba language lends itself to morphemic prefixation only in its word formation. This is significant in second language learning as it implies that ESL teachers could use these areas of contrasts and similarities as effective teaching devices to teach and correct interference errors among learners.
\end{abstract}

Index Terms—affixation, prefixation, suffixation, inflection, morphology

\section{INTRODUCTION}

The comparison between English and Yoruba affixation processes is presented based on the understanding that both languages are socio-culturally linked. According to Gast (2012), "two languages can be said to be socio-culturally linked when (i) they are used by a considerable number of bi- or multilingual speakers, and/or (ii) a substantial amount of 'linguistic output' (text, discourse) is translated from one language into the other". Hence, English and Yoruba are comparatively described in this study to highlight point of differences and similarities for the purpose of teaching English effectively. The idea of contrasting two socio-culturally linked languages was first instigated by Fries (1945) who opined that "the most effective materials in foreign language teaching are those that are based upon a scientific description of the language to be learned (L2), carefully compared with a parallel description of the native language of the learner (L1)".

However, this school of thought soon met with strong criticisms as some short comings are identified. For instance, Kortmann (1998) and a host of other linguists are of the view that:

Contrasting a pair of languages turned out to be too optimistic. It was too undifferentiated in many respects and neglected important parameters of second language acquisition (e.g. natural vs. mediated, sequential vs. simultaneous, second vs. third language, etc.). Moreover, the contrastive programme lacked a solid foundation in learning psychology and was never even put on a reasonable empirical basis, insofar as the intention of producing comprehensive comparisons of language pairs was never convincingly realized.

The initiative of improving foreign or second language teaching on the basis of comparing two languages was therefore abandoned before long, even though a certain plausibility of at least some of the basic assumptions made by early contrastive linguistics can hardly be denied. To this end, Lado (1957) provides a comparative description of English and Spanish based on the assumption that foreign or second language teaching can be enhanced by comparing the learner's native language (mother tongue) with the language to be learned (target or second language) and this transpires to "Contrastive Hypothesis". König \& Gast (2008) summarize the concept of contrastive analysis as follows:

1. There is a fundamental difference in first language acquisition and foreign language learning especially in situations where the foreign language is learnt later than a mother tongue and on the basis of the full mastery of that mother tongue.

2. All languages have their distinct or specific structures. Similarities between the two languages will cause no difficulties ('positive transfer'), but differences will, due to 'negative transfer' (or 'interference'). This suggests that learners' learning task revolves around the differences at linguistic levels between the two languages.

3. As a result, the systematic comparison between mother tongue and foreign language to be learnt will reveal both similarities and contrasts.

4. Such a comparison makes it possible to predict or even rank learning difficulties and to develop strategies (teaching materials, teaching techniques, etc.) for making foreign language teaching more efficient. 
In Second Language Acquisition, the mastery of non-native grammars is imperative because learners' variability manifests in the degree of non-native grammar mastery where some achieve a near-native command and others fail. Apparently, failure or error would easily occur in situations where the grammar of the mother tongue is transferred into the target language to express or communicate ideas. This emanates as a result of the peculiarities embedded in the word arrangement systems of different languages.

\section{Words arrangements}

The word is the basis of all human communication as well as all language learning and teaching efforts. Arrangements of words lead to syntax and other linguistic levels that bring about intelligible and effective communications. However, languages differ in their word arrangement processes which implies that a language's morphological system needs to be uniquely identified and established from the other in a second language acquisition class to avoid interlanguage and language transfer errors (Weinreich, 1955).

A word is made up of morphemes which are described by Bloomfield (1933) as linguistic forms that bear no partial phonetic or semantic resemblance to any other form. Nida (1949) sees morphology as the study of morphemes and their arrangements in the formation of words. Thus, the process where new words are formed by attaching morphemes to new words is referred to as affixation. Such morphemes could be added at the initial position (prefix) or final position (suffix) of the words; still, some morphemes could be added in the middle (infix) but this process is not common in both English and Yoruba. Thus, prefixes, suffixes and infixes constitute affixation in any language; however, the three processes may not occur at once in a particular language.

For the purpose of this study, the descriptions of affixation processes in English and Yoruba is limited to verbs, nouns and pronouns because these word classes best illustrate inflectional and derivational processes in the two languages.

\section{Affixation processes in English (Prefixes and Suffixes)}

A process where new words are formed through the addition of morphemes is referred to as affixation. These morphemes could be added at the beginning (before) or end (after) of the root word. When a morpheme is added at the beginning, is called a prefix and when it is added at the end, it is called a suffix. It should be noted however that some words have both prefixing and suffixing of their root forms. When morphemes are added before root morphemes (prefix) for instance in English, it denotes a sense of negation thus changing polarity from positive to negative but suffixes denote inflections which could change the form of the root morpheme totally after it has been added or retain the form. In other words, suffixes could be inflectional or derivational. Tomori (1977) defines inflectional suffix as a morpheme that performs a grammatical function in a word without changing the word class of the particular word. On the other hand, derivational morphemes are added to derive entirely new words from the original morphemes.

In English, both prefixing and suffixing processes are employed to form words. For instance, prefixing is derivational while suffixing could be both derivational and inflectional and since inflectional suffixes always come at the end of a word, it is therefore regarded as terminal.

The following tables present some English words which are formed by prefixation and suffixation processes.

TABLE 1:

ENGLISH WORDS FORMED BY DERIVATIONAL PREFIXES

\begin{tabular}{|l|l|l|l|}
\hline Morphemes (Prefixes) & Root morphemes & Derived words & Word class \\
\hline im- & im + possible & Impossible & Adjective \\
un- & un + common & uncommon & \\
mis- & mis + fit & misfit & \\
il- & il + legal & illegal & \\
dis- & dis + regard & disregard & \\
em- & em + ploy & employ & \\
re- & re + cap & recap & \\
pre- & pre + tax & pre-tax & \\
ex- & ex + convict & ex-convict & \\
sub- & sub + way & indifferent & \\
in- & in + different & pro-chancellor & \\
pro- & pro + chancellor &
\end{tabular}

Inflectional suffixes in English are best presented through the English verbs where inflection is considered highly productive. English verbs are basically categorized into the base form or to- infinitive e.g to jump, the $-\mathbf{s}$ form e.g jump $+s=j u m p s$, the -ing form e.g jump +ing=jumping, the-ed form e.g jump $+e d=j u m p e d$, and the -en form e.g jump +en= jumped. It should be noted that these suffixes indicate tenses such as simple present tense, present continuous tense, simple past tense and past participle tense respectively.

TABLE 2:

ENGLISH WORDS FORMED BY SUFFIXATION (INFLECTIONAL)

\begin{tabular}{|l|l|l|l|}
\hline Morphemes (Suffixes) & Root morphemes & Derived words & Word class \\
\hline -s & jump + s & Jumps & simple present tense \\
-ed & jump + ed & jumped & simple past tense \\
-ing & jump + ing & jumping & present continuous \\
-en & jump + en & jumped & past participle \\
\hline
\end{tabular}


Inflectional suffixes are also prominent in English nouns to reflect number as in singular and plural forms. This is indicated by such suffixes as - $\mathbf{s}$, - -es, -ies, -en. It should be noted however that plural morpheme -s and the possessive marker $-\mathbf{s}$ has phonologically conditioned allomorphs which are /s/, /z/, and /iz/. Hence, the - s allomorph follows unvoiced consonants such as cats, bats, taps; the $-\mathrm{Z}$ allomorph follows vowels and voiced consonants such as John's and cows; and -iz come after affricates and fricatives such as churches, judges (affricates) and pieces, roses and bushes (fricatives). In addition, there is the zero allomorph (no morphemic difference between the singular and plural forms) in such words as sheep and deer.

English pronouns are also inflected and they are categorized into three groups: personal, relative and demonstrative pronouns. While personal and relative pronouns are classified according to their position or function in a sentence, demonstrative pronouns are inflected for number only. Positions occupied in sentences by personal or relative pronouns are subject/object position or they indicate an epithetic possessive/predicative possessive case. For instance, the table below explains these categorizations according to functions:

TABLE 3:

INFLECTIONS IN ENGLISH PERSONAL AND RELATIVE PRONOUNS

\begin{tabular}{|l|l|l|l|}
\hline Subjective & Objective & Epithetic possessive & Predicative possessive \\
\hline I & Me & My & Mine \\
We & Us & Our & Ours \\
You & You & Your & Yours \\
He & Him & His & His \\
She & Her & Her & Hers \\
It & It & Their & Its \\
They & Them & Whose & Theirs \\
Who & Whom & & Whose \\
Which & Which & \\
That & That & \\
This & This & \\
Those & Those & \\
These & These & \\
\hline
\end{tabular}

\section{Affixation Processes in Yoruba (Prefixation)}

The Yoruba language is a Kwa language of Western Nigeria. One of the morphological processes it employs for its word formation is the affixation process which is identified as the key operation for the formation of most words in the language. In other words, Yoruba words are formed by certain morphological principles which define the internal structure of such words. By the application of such principles, words get their syntactic as well as semantic features which precede phonological rules of adjustment.

The Yoruba language is seldom inflected neither does it exhibit suffixation (Tinuoye, 1991). The first peculiarity of the Yoruba language is the complete and regular system of prefixes by which words are formed. This is a prominent feature in the language, and it is prone to an indefinite extent. The original idea contained in the simple verb, for instance, may be modified in a variety of ways, and carried through numerous relations, without complexity, by the mere addition of prefixes, in such a regular system that it is almost impossible to mistake the meaning of the compound product. For instance, the Yoruba word 'alaigbagbo' (unbeliever) has the root word 'gbagbo' (believe) and two morphemes 'al' (agentive) and 'ai' (negator) are prefixed to derive the negative word 'alaigbagbo'.

For instance, root words (e.g. verbs) expressing the simple idea of acting e.g. se, (do); fe, (love); mo, (know); lo, (go) can abstractedly state the action denoted by the verb, by taking the prefix ' $i$ ' thus, changing the word class from verb to noun: ise, (the action or act of doing=work) ife, (the act of loving=love) imo, (the act of knowing= knowledge) ilo, (the act of going).

The different prefixation processes Yoruba employs to derive changes in polarity (positive to negative) contrasts English which is inflection by suffixation. Yoruba lends itself therefore to derivational prefixation in which a complete and regular system of prefixes occurs to form new words. The primary functions of prefixes when used with monosyllabic verbs in Yoruba are to:

(1) derive concrete nouns denoting the actor or agent in a sentence are derived by the combination of an agentive nominal and a verb (doing word) e.g.

a) the prefix a + pa (kill) eja (fish) means (kill a fish) = "apeja" (a fisherman); a+ ko + (verb) orin (song) means (sing a song) $=$ akorin $($ a singer $)$.

b) the word adé (personal name)/‘crown' - prefix 'a' + 'dé' (cover) $=a+$ dé $=$ adé.

(2) to denote the receiver e.g. the prefix $a+$ verb mu (to drink) $=$ amu (water pot); the prefix o + fi (to swing) $=$ ofi (loom) and

(3) the action or state of being e.g. verbs expressing the simple idea of acting e.g. se, (do); fe, (love); can abstractedly state the action denoted by the verb, by taking the prefix ' $i$ ' + se $=$ ise, (the action or act of doing=work) $i+f e=i f e,($ the act of loving=love) (Crowther, 1852).

Affixation produces Yoruba nouns by prefixing Yoruba verbs with any of the six out of the seven Yoruba vowels (a, e, ẹ, i, o, ọ) and by in-flect. 
TABLE 4:

FORMATION OF YORUBA NOUNS BY PREFIXING VOWELS TO VERBS

\begin{tabular}{|c|c|c|c|}
\hline Vowels & Yoruba Verbs & Verb Meaning & Nouns \\
\hline E & Wa & Come & $\mathrm{E}+\mathrm{wa}=$ ewa (boiled beans/ Beauty) \\
\hline I & Ș ẹ & Cut & I + ș ẹ = ise (poverty, work) \\
\hline $\mathrm{E}$ & $\mathrm{Wu}$ & Swollen & $\mathrm{E}+\mathrm{wu}=\mathrm{ewu}$ (danger, gray hair, large nocturnal rodent) \\
\hline $\mathrm{E}$ & wọ & Enter & $\grave{\mathrm{E}}+\mathrm{wọ}=$ ewo (forbidden, abomination) \\
\hline I & $\mathrm{Ju}$ & Throw & $\begin{array}{l}\mathrm{I}+\mathrm{ju}=\mathrm{iju} \text { (wilderness, false conception, disease which } \\
\text { prevents pregnancy in women) }\end{array}$ \\
\hline O & $\mathrm{Ba}$ & $\begin{array}{l}\text { overtake, ambush, } \\
\text { perch }\end{array}$ & $\mathrm{O}+\mathrm{ba}=$ oba (king in Yoruba) \\
\hline $\mathrm{E}$ & Jo & to dance & $\mathrm{E}+$ jo $=$ ejo $($ snake $)$ \\
\hline $\mathrm{E}$ & Yin & To praise & $\mathrm{E}+\mathrm{yin}=$ eyin $(\mathrm{egg} / \mathrm{palm}$ tree nut $)$ \\
\hline A & Dun & Sweet & $\mathrm{A}+$ dun $=$ adun (prefix to form name Adunola, sweet) \\
\hline I & $\mathrm{Ru}$ & Carry & $\mathrm{I}+\mathrm{ru}=$ iru (locust bean, tse-tse fly) \\
\hline $\mathrm{O}$ & Wo & Collapse, break, fall & $\mathrm{O}+\mathrm{wo}=$ owo (money) \\
\hline
\end{tabular}

Also, nouns of possession are formed by prefixing a vowel to this verb, which varies according to a determinate rule. Where the form ' $\mathrm{ni}$ ' is retained, the prefixed vowel 'o' is needed : in the other cases it is the same as the initial vowel of the noun which denotes the thing possessed ; thus, onidajo, " one who judges ;" alaimo, " one who is ignorant;" elese, " one who has sin ;" olowo, "one who possesses money;" olorun, "one who possesses, or is in, heaven." The following list of derivatives from 'se' will throw more light on the above-described formation of nouns.

se "sin," the original idea of the verb (the act of sinning)

$\mathbf{e}+\mathbf{s e}=\mathbf{e s e}$ "sin," the noun, an irregular formation.

le $+\mathbf{s e}=$ lese " to have sin," verb of possession.

ele + se/ oni+ ese $=$ elese " one who has sin," noun of possession.

$\mathbf{a}+\mathbf{i l}+\mathbf{e s e}=$ ailese "not having sin."

la $+\mathbf{i l}+\mathbf{e s e}=$ lailese " to possess freedom from having sin."

$\mathbf{a}+\mathbf{l a}+\mathbf{i l}+\mathbf{e s e}=$ alailese " one who possesses freedom from having sin."

Regardless of how it is formed, Yoruba nouns start with a vowel like $(\mathrm{a}+$ bayomi $=$ Abayomi), consonant $(\mathrm{b}+$ ankole $=$ Bankole $)$ or diphtongue such as $(\mathrm{gb}+$ olahan = Gbolahan, Gbolagunte, Gbolade, Gbolaga). Unlike, some English nouns with one syllable, Yoruba nouns are bi, tri or multi-syllable.

\section{Formations of Yoruba Pronouns}

Yoruba is strictly SVO, and the $3^{\text {rd }}$ person singular object simply copies the vowel of the preceding verb, an iconic representation of the extension or completion of the verbal activity, as in (1).

\section{(1) O fà á 'He pulled it.'}

O sí í 'He opened it.'

The other persons have distinct subject and object pronouns, used only with verbs. There is also a set of emphatic pronouns whose usage is not restricted.

TABLE 5:

YORUBA PERSONAL PRONOUNS

\begin{tabular}{|c|c|c|}
\hline \multicolumn{3}{|c|}{ SONAL PRONOUNS } \\
\hline Subject & Object & Emphatic \\
\hline Ist Person singl $\mathbf{m o}$ & Ist Person singl $\mathbf{m i}$ & Ist Person singl $\boldsymbol{e m i}$ \\
\hline $2^{\text {nd }}$ Person singl $o$ & $2^{\text {nd }}$ Person singl $\boldsymbol{o} / \boldsymbol{e}$ & $2^{\text {nd }}$ Person singl iwo \\
\hline $3^{\text {rd }}$ Person singl $o$ & $\begin{array}{l}3^{\text {rd }} \text { Person singl repetition of the last vowel } \\
\text { of the verb }\end{array}$ & $3^{\text {rd }}$ Person singl oun \\
\hline $1^{\text {st }}$ Person plural $\boldsymbol{a}$ & $1^{\text {st }}$ Person plural $w a$ & $1^{\text {st }}$ Person plural awa \\
\hline $2^{\text {nd }}$ Person plural $\boldsymbol{e}$ & $2^{\text {nd }}$ Person plural nyin & $2^{\text {nd }}$ Person plural ènyin \\
\hline $3^{\text {rd }}$ Person plural nwon & 3rd Person plural won & 3rd Person plural awon \\
\hline
\end{tabular}

There are obvious differences between the realizations of pronouns in English and Yoruba as seen from the two tables. The tendency is that ESL learners may transfer the features of the dominant language (Yoruba) to the target language (English) at the phonological, lexical, grammatical and discourse levels. Hence, ESL teachers need to identify 
and bring learners' attention to the areas of differences and teach accordingly (Ikeddeh, 1986). The table below compares the two languages' formations and functions of pronouns.

\section{Methodology}

It is established that some aspects in grammar exist in both languages as specified above, for example, both English and Yoruba have personal pronouns. Both are then compared and contrasted to indicate similarities and differences for pedagogic implications.

TABLE 6:

A COMPARISON OF YORUBA AND ENGLISH PERSONAL PRONOUNS

\begin{tabular}{|c|c|c|c|c|c|c|c|c|}
\hline & Singular & & Possessi & & Objective & & Plural & \\
\hline $\begin{array}{l}\text { Personal } \\
\text { Pronoun }\end{array}$ & English & Yoruba & English & Yoruba & English & Yoruba & English & Yoruba \\
\hline $\begin{array}{l}1^{\mathrm{ST}} \\
\text { Person }\end{array}$ & I & Emi, Mi & $\begin{array}{l}\text { Mine, } \\
\text { My }\end{array}$ & $\begin{array}{l}\text { Mi, } \\
\text { T’emi, } \\
\text { Ti’wa }\end{array}$ & $\mathrm{Me}, \mathrm{Us}$ & $\begin{array}{l}\mathrm{Mi}, \\
\text { 'Wa }\end{array}$ & We & Awa, A \\
\hline $2^{\text {nd }}$ Person & You & Iwọ & $\begin{array}{l}\text { Our, } \\
\text { Our's }\end{array}$ & $\begin{array}{l}\text { Ti'ẹ } \\
\text { Ti yin, }\end{array}$ & You & $\begin{array}{l}\text { Ti'ẹ } \\
\text { Fun yin }\end{array}$ & $\begin{array}{l}\text { You' } \\
\text { Your }\end{array}$ & Awa \\
\hline $\begin{array}{l}3^{\text {rd }} \text { Person } \\
\text { (Male) }\end{array}$ & $\mathrm{He}$ & Oun, $\mathrm{O}$ & His & $\begin{array}{l}\text { Ti’ẹ } \\
\text { Tirẹ }\end{array}$ & Him & Rẹ, E & - & - \\
\hline $\begin{array}{l}3^{\text {rd }} \text { Person } \\
\text { (Femal) }\end{array}$ & She & Oun, O & $\begin{array}{l}\text { Her, } \\
\text { Hers }\end{array}$ & $\begin{array}{l}\text { Ti'ẹ } \\
\text { Tirẹ }\end{array}$ & Her & Rẹ, E E & - & - \\
\hline $\begin{array}{l}3^{\text {rd }} \text { Person } \\
\text { Plural }\end{array}$ & - & - & $\begin{array}{l}\text { Their } \\
\text { Theirs }\end{array}$ & $\begin{array}{l}\text { Ti wọn } \\
\text { Ti' wọn }\end{array}$ & Them & Wọn & They & $\begin{array}{l}\text { Ti wọn, } \\
\text { Wọn, } \\
\text { Awọn }\end{array}$ \\
\hline $\begin{array}{l}3^{\text {rd }} \text { Person } \\
\text { Neuters }\end{array}$ & It & $\mathrm{O}$ & Its & Ti’ ẹ & Its & Ti’ẹ & - & - \\
\hline \multirow[t]{2}{*}{$\begin{array}{l}3^{\text {rd }} \text { Person } \\
\text { Neuters }\end{array}$} & One & $\begin{array}{l}\text { Eleyi } \\
\text { (This } \\
\text { One) }\end{array}$ & One's & Eleyi & One & Eleyi & - & - \\
\hline & Who & Tani & Whom & Ti’ ẹ & One & Eleyi & - & - \\
\hline
\end{tabular}

\section{Comparing functions of English and Yoruba Pronouns}

The Yoruba language is basically described as a humanistic language and language of respect. The language, consistent with the ethics of an African Yoruba philosophy-humanizes persons and social beings in situations of discourse. The language pays close attention to official/situations of respect and informal/ situations of familiarity of users. For example, You /Iwo is 2nd person singular (emphatic subject pronoun). You/Eyin is also 2nd person singular (emphatic subject pronoun). But Eyin/yin functions as plural form and respect/official form. For example,

Eyin/You

Eyin ti jẹun (You (plural-more than one person) have eaten).

Eyin ti jẹun (You (singular (respect/official situation) have eaten).

$J e$ is to eat (when used you include type of food.)

Jeun is to eat food (when used you do not include the type of food)

Je ounje is to eat food.

Je fufu (eat fufu)

$M o$ jẹun ( $I$ ate or $I$ ate food)).

$M o$ jẹ fufu ( $I$ ate fufu)

Ounjẹ means food.

Yin /You (object pronoun)

Mo (subject) fun yin (object). (I give/gave you) Mo (I) fun (give/gave) yin (you).

Yin/you in the sentence is the object of the verb fun/give/gave. And Yin functions as You plural and $Y o u$ in a respect/official situation.

Awon/They (subject pronoun) in an emphatic form.

Awọn (subject pronoun in emphatic form) ti jẹun. / They (plural) have eaten.

Wọn (subject pronoun in non-emphatic form) ti jẹun. / They (plural) have eaten. 
Won ti jẹun. She/He has eaten. He/She in a respect/official situation.

Won/Them (object pronoun in respect/plural form)

Mo (subject) fun won (object) / I gave/give you.

Won /you in a plural situation. Also won/you in a respect/official/formal situation.

\section{O/Oun/You}

The Pronoun O/Oun is gender neutral. So it stands for He/She/It

\section{RESULTS AND ANALYSIS}

Based on the comparisons made in the functions of pronouns in English and Yoruba languages, implications of similarities and differences for pedagogy are therefore presented as follows.

\section{Pedagogic Implications}

Interference is a psycho-linguistic concept which is a reality in language learning. Errors in second language learning are partly attributable to interference. Theorists of interference believe that acquisition of the first language usually affects performance in subsequent language acquired. Interference as a linguistic problem is common in communities where second languages (usually the lingua franca) must be learnt. In other words, interference is a term which refers to a situation whereby two different languages overlap. For instance, English verbs are inflected (suffixation) for past with the use of '-ed' as in 'danced', 'jumped', "He danced beautifully". "Yesterday, she jumped over the fence". However, a Yoruba learning English may say *"Yesterday she jump over the fence" because Yoruba does not mark the past tense with suffix morphemes rather the past tense is prefixed with adverbs. "L'ana omobirin naa fo iganna". Also, learners tend to overgeneralize some grammatical rules in the use of English verbs because they do not understand the grammatical principle guiding the target language. This necessitates teachers' efforts at presenting the two grammars to the learners for the purpose of clarification and identification in usage. The table below presents some errors committed by Yoruba learners of English as recorded by Adebileje (2013):

TABLE 7:

MISUSE OF VERBAL FORMS

\begin{tabular}{|c|c|c|c|}
\hline No & Examples of error & Types of error & Correct structures \\
\hline & 1.She wanted to sewed a new dress. & Inflecting infinitive to sew for past tense. & 1. She wanted to sew a new dress. \\
\hline & 2. The boy has laid there for many days. & Use of past $-\boldsymbol{e d}$ for $-\boldsymbol{e n}$. & 2. The boy has lain there for many days. \\
\hline & 3. You have bursted the secret. & Inflecting irregular verb for past. & 3. You have burst the secret. \\
\hline & 4. The terrorist has been hung. & Overgeneralization of -en participle. & 4. The terrorist has been hanged. \\
\hline & 5. The students seeked new directives. & $\begin{array}{l}\text { verbs. } \\
\text { vallat }\end{array}$ & 5. The students sought new directives. \\
\hline & 6. The lady would have grinded the beans. & ” & 6. The lady would have ground the beans. \\
\hline & 8. The water freezed quickly. & Using simple $-\boldsymbol{e d}$ for $-\boldsymbol{e n}$. & 8. The water froze quickly. \\
\hline & $\begin{array}{l}\text { 9. The rain started when the boys have } \\
\text { slept. } \\
\text { 10.She has flied abroad. }\end{array}$ & $\begin{array}{l}\text { Overgeneralization. } \\
\text { Auxiliary still in the present while main } \\
\text { verb is - ed. } \\
\text { Using simple - ed for - en. }\end{array}$ & $\begin{array}{l}\text { 9. The rain started when the boys had slept. } \\
\text { 10. She has flown abroad. }\end{array}$ \\
\hline
\end{tabular}

Students' linguistic background therefore, needs to be identified by English teachers in order to forestall the problem of interference (Igbonusi, 2000). This study has exposed teachers to the syntax of English and Yoruba languages' problem areas at the word formations levels (morphological processes) as well as differences in the functions of words such as nouns, pronouns (personal and relative pronouns). In a study carried out by Adebileje (2013), learners' errors (that is, Yoruba learners of English) in the use of English pronouns can be avoided when teachers contrast word formation processes between the two languages systematically taking note of the fact that Yoruba pronouns' formation process and usage are quite different from English. Such errors in the use of English pronouns are presented in tabular form thus: 
TABLE 8:

MISUSE OF PRONOUNS

\begin{tabular}{|c|c|c|c|}
\hline No & Туре of error & Examples of error & Correct structures \\
\hline & $\begin{array}{l}\text { 1. The man which came here yesterday } \\
\text { danced. } \\
\text { 2. There is no difference between Niyi and } \\
\text { I. } \\
\text { 3. The couple love themselves. } \\
\text { 4. It seems to be them that did the project. } \\
\text { 5. Clean homes are essential to we } \\
\text { mothers. } \\
\text { 6. It was she that took the camera. } \\
\text { 7. Sade is taller than me. } \\
\text { 8. The bull ran after Faith and I. } \\
\text { 9. The nurse which child returned has } \\
\text { come. } \\
\text { 10.The group members love each other. }\end{array}$ & $\begin{array}{l}\text { Misuse of which (inanimate) for who (animate) } \\
\text { relative pronouns. } \\
\text { Subjective case (I) instead of objective case } \\
\text { (me). } \\
\text { Confusing reciprocal with reflexive pronouns. } \\
\text { Misuse of objective for subjective case. } \\
\text { Misuse of subjective for objective case. } \\
\text { Misuse of objective case for subjective case. } \\
\text { " } \\
\text { " } \\
\text { Misuse of relative (which) for possessive } \\
\text { (whose). } \\
\text { Confusing each other with one another. }\end{array}$ & $\begin{array}{l}\text { 1. The man who came here yesterday } \\
\text { danced. } \\
\text { 2. There is no difference between Niyi } \\
\text { and me. } \\
\text { 3. The couple loves each other. } \\
\text { 4. It seems to be they that did the project. } \\
\text { 5. Clean homes are essential to us } \\
\text { mothers. } \\
\text { 6. It was her that took the camera. } \\
\text { 7. Sade is taller than } I \text {. } \\
\text { 8. The bull ran after Faith and me. } \\
\text { 9. The nurse whose child returned has } \\
\text { come. } \\
\text { 10. The group members love one } \\
\text { another. }\end{array}$ \\
\hline
\end{tabular}

These errors according to Adebileje (2013) "are indications that students are not well grounded in their foundational grammar classes, hence, the confusion exhibited. Therefore, lecturers should endeavor to elicit specific classification and usages and if need be do some drillings to ensure tangible understanding in learners".

\section{CONCLUSION}

Teachers must always be guided by the fact that mother tongue affects learners' understanding of grammatical rules of target language because the two are of different models. Systematic modules of forms and usages peculiar to each language must be painstakingly taken care of by second language teachers hence, the need for this kind of comparison. In corroboration, Corder (1981) advises that learners need to be re-taught and re-drilled in the differences and similarities between their L1 and the target language with special emphasis on areas that are different.

\section{REFERENCES}

[1] Adebileje, A.O. (2013). Syntactic Errors of Nigerian Undergraduates in English: The Role of the First Language (L1) and Pedagogical Implications. International Journal of Science Commerce and Humanities. Vol.1, No.1. (93-105).

[2] Bloomfield, L. (1933). Language. New York: Holt, Rinehart and Winson, Inc.

[3] Corder, S.P. (1981). Error Analysis and Interlanguage. Oxford University Press, London.

[4] Crowther, S.A. (1852). A Grammar and Vocabulary of Yoruba Language. The Smithsonian Institute.

[5] Fries, C.C. (1945). Teaching and learning English as a foreign language. Ann Arbor: University of Michigan Press.

[6] Fromklin, V.; Rodman, R;. \& Hyams, N. (2003). An Introduction to Language. Heinle: Thomson Wadsworth Corporation.

[7] Gast,V. (2012). Contrastive Linguistics: Theories and Methods. In Kortmann, B. and J. Kabatek (eds.), Dictionaries of Linguistics and Communication Science: Linguistic theory and methodology. Berlin: Mouton de Gruyter.

[8] Igbonusi, H.S. (2000). Contrastive Analysis: some problem areas for the Igbo Learner of English in Adeyemi O.B. (ed) Studies in English Language Ibadan, Enicrownfit Publishers.

[9] Ikeddeh, E. (1986). English, Bilingualism and National Language Policy for Nigeria in S.O. Unoh (ed) Use of English in Communication: The Nigeria experience (1986). Ibadan, spectrum Books Ltd.

[10] König, E. and Gast, V. (2008). Understanding English-German Contrasts. 2nd edition (revised). Berlin: Erich Schmidt Verlag.

[11] Kortmann, B. (1998). Kontrastive Linguistik und Fremdsprachenunterricht. In: W. Börner/K. Vogel, eds. Kontrast und Äquivalenz. Beiträge zu Sprachvergleich und Übersetzung. Tübingen: Narr. 136-167.

[12] Lado, R. (1957). Linguistics across cultures: Applied linguistics for language teachers. Ann Arbor: University of Michigan Press.

[13] Nida, E.A. (1949). The identification of morphemes, in Morphology: The Descriptive Analysis of Words, 2ed, 6-61. Ann Arbor: University of Michigan Press.

[14] Tinuoye, M.O. (1991). A Contrastive Analysis of English and Yoruba Morphology. Ibadan: Tafak Publications.

[15] Tomori, S.H. (1977).The morphology and syntax of present-day English: An introduction. Heinemann Educational (London).

[16] Weinreich, U. (1953). Language in contact: The Hague, Monton and Co.

Adebola Omolara Adebileje was born in Port Harcourt, Nigeria and had her Master's degree in Education (English Language), 1998 and PhD in English Education, 2002 at the University of Ilorin, Ilorin, Kwara State, Nigeria. The author's major fields are Applied English Linguistics, Sociolinguistics and Transformational Syntax. The author is also interested in Onomastic.

She lectures APPLIED ENGLISH LINGUISTICS, TRANSFORMATIONAL SYNTAX AND NIGERIAN ENGLISH: FORMS AND USAGE at the Redeemer's University, Ogun State, Nigeria. She has published papers in notable international journals. Her current research interest is Corpus of Contemporary Nigerian English for Pedagogy.

Dr. Adebileje is a member of the Nigerian English Studies Association (NESA), Linguistic Association of Nigeria (LAN), Reading Association of Nigeria (RAN), American Association of Applied Linguistics (AAAL), Linguistics Society of America 
(LSA), American Names Society (ANS), and Society for the Study of Names in Nigeria (SSNN). She is an active member of Group Editors (an editing outfit) and a reviewer for Asian Journal of Education and E-learning (AJEEL). 